OPEN ACCESS

Edited by:

Victor Kuete,

University of Dschang, Cameroon

Reviewed by:

Christian Agyare

Kwame Nkrumah University of Science and Technology, Ghana Helen Skaltsa,

National and Kapodistrian University of Athens, Greece

${ }^{*}$ Correspondence:

Parshuram Nivrutti Shendge

shendge.parshuram@gmail.com

Specialty section:

This article was submitted to Ethnopharmacology, a section of the journal

Frontiers in Pharmacology

Received: 17 April 2018 Accepted: 28 September 2018

Published: 22 October 2018

Citation:

Shendge PN and Belemkar S (2018)

Therapeutic Potential of Luffa acutangula: A Review on Its Traditional Uses, Phytochemistry,

Pharmacology and Toxicological Aspects. Front. Pharmacol. 9:1177.

doi: 10.3389/fphar.2018.01177

\section{Therapeutic Potential of Luffa acutangula: A Review on Its Traditional Uses, Phytochemistry, Pharmacology and Toxicological Aspects}

\author{
Parshuram Nivrutti Shendge* and Sateesh Belemkar \\ Department of Pharmacology, School of Pharmacy and Technology Management, SVKM's NMIMS, Dhule, India
}

Luffa acutangula (Cucurbitaceae), a perennial plant grows mainly in India, Southeast Asia, China, Japan, Egypt, and other parts of Africa, it is widely used in the traditional Indian medicinal system to treat various health conditions. The plant has been used in jaundice, diabetes, hemorrhoids, dysentery, headache, ringworm infection, and leprosy. More than 50 chemical compounds have been isolated from a plant which mainly comprises flavonoids, anthraquinones, proteins, fatty acids, saponin triterpene, volatile components, and other phytoconstituents. Crude extract of plant and its isolated compounds possess broad pharmacological activities such as antidiabetic, hepatoprotective, antiulcer, anticancer, immunomodulatory, antihyperlipidemic, antioxidant, antimicrobial, CNS depressant, analgesic, and anti-inflammatory. The toxicological evaluation in preclinical studies reported safety of the plant for human consumption, but comprehensive evaluation in clinical studies is required. However, further investigation is necessary for transformation of experience based treatment of plant into evidence based information. Evaluation of pharmacological activity with indicative biomarkers will help to reveal the mechanism of action of chemical constituents of plant extract. The data from preclinical studies recommends clinical evaluation of safety and efficacy of the plant. The current paper summarizes up-to-date information about a review of the traditional uses, phytochemistry, pharmacological activities, and toxicology to highlight the future prospects of the plant.

Keywords: Luffa acutangula, traditional medicine, anthraquinones, saponin triterpene, antidiabetic activity, antioxidant activity

\section{INTRODUCTION}

Medicinal compounds from plant sources play a key role in prevention and treatment of disease since ancient time. Some of these compounds are toxic to plant predators, but have the beneficial effects in the treatment of human diseases. Demand for compounds isolated from plants is growing throughout the world and many pharma companies are currently conducting extensive research of these compounds in human health (Danish et al., 2011).

Luffa acutangula is a medicinal plant, usually referred as a ridge gourd. It is prevalent in subtropical region of Asia. India is considered as a primary center of origin. The plant is widely cultivated in India, Southeast Asia, China, Japan, Egypt, and other parts of Africa. Propagation of 
this plant is done through seeds and are sown in February-March or June-July (Munshi et al., 2010).

The purpose of the present review is to analyze the traditional uses, phytochemistry, pharmacological activity, and toxicological studies of plant. Moreover, the knowledge obtained from various experimental studies was critically assessed to provide justification for traditional and medicinal uses of Luffa acutangula.

\section{BOTANICAL ASPECTS}

Luffa acutangula (L.) Roxb. is classed in the Cucurbitaceae, a family of flowering of plants with 98 accepted genera and about 975 species. Many of the annual or perennial species native to temperate and tropical areas are fruit bearing or ornamental plants (Lucas et al., 2010; Encyclopaedia Britannica, 2018). The synonyms of plants are Cucumis acutangulus, Cucurbita acutangula, Luffa foetida, Luffa drastica, Cucumis operculatus Roxb., Luffa gosa Ham. (Quattrocchi, 2012).

The plant has different names in different languages of India such as: English: Ridged gourd, angled loofah, ribbed gourd, Chinese okra, silk squash (En); Hindi: Turai, Kadaviturai; Marathi: Dodaka; Sanskrit: Dhamargava, Koshataki; Bengali: Titotorai, Titojhinga, Titodhundal, Jhinga, Ghoshalata; Kannada: Kahire, Kahi heere, Naaga daali balli; Malayalam: Athanga; Tamil: Itukari, Itukarikkoti, Kacappi, Kacappuppirkku, Kaccam, Kaippuppirkku, Karniti; Telugu: Adavibira, Chedubira, Sendubirai, Adavi beera, Chathi beera (Nadkarni, 1996).

The roots of the plant are yellowish brown in color and cylindrical in shape. Longitudinal wrinkles on root contribute to their rough texture. Five angled, glabrous stem is brownish yellow in color along with tendrils up to 6-fid. Flowers are regular, unisexual and consists of yellow petals. Female flowers are yellow colored solitary, $2-15 \mathrm{~cm}$ long on pedicels, with inferior, longitudinally ridged ovary and 3-lobed stigma while male flowers are light greenish in color, consist of three free stamens with yellow corolla inserted into the receptacle tube. Leaves are simple, alternate and orbicular in outline with 15-20 cm long, palmately 5-7 angled, triangular to broadly rounded lobes and pale green in color. Veins and vein islets are prominent. Fruits are cylindrical, pale yellowish-brown in color, bitter in taste, tapered toward the base and are covered with 8-10 prominent ribs. Inner part of the fruit is three chambered, fibrous and easily detachable from the outer part. Seeds are elliptical and black colored (Basu and Kirtikar, 1987).

\section{TRADITIONAL USES AND ETHNOPHARMACOLOGY}

Different parts of Luffa acutangula have been used extensively by different ethnic groups in India for medicinal purposes. In Maharashtra and the tribal areas of Madhya Pradesh, leaves and fruit powder are used for the treatment of jaundice (Das and Basu, 1997; Samvatsar and Diwanji, 2000).
A local inhabitant from reserve forest of Mahadevpur (previously in Andhra Pradesh now in Telangana) widely uses the fruit for diabetes treatment (Kanaka et al., 2013). Apart from this, the plant is also used by the tribes of western Maharashtra on insect bite. Fruit powder is applied topically to treat swollen hemorrhoids. The kernel of the seed is used as an efficient remedy for dysentery while the juice of the fruit is applied to cure a headache (Dandge et al., 2010). Oral administration of seed powder is extensively used for the treatment of urinary bladder stone in Rajasthan (Katewa et al., 2004). Local application of pulverized leaves is reported to be useful in splenitis, hemorrhoids, ringworm infection, and leprosy while the juice of the leaves is administered into the eye for treatment of granular conjunctivitis in children (Mahbubar, 2013). In addition, the fruit possesses demulcent and diuretic properties while the seeds have purgative, emetic and anthelmintic properties. The dried fruit powder is useful in preventing premature graying of hair. The root of the plant is laxative and used in dropsy (Nadkarni, 1996).

\section{PHYTOCHEMISTRY}

The phytochemical studies have resulted in isolation and identification of approximately 50 compounds, such as flavonoids, anthraquinones, proteins, fatty acids, saponin triterpene, volatile components, and other phytoconstituents (Table 1).

\section{Proteins}

Various ribosome inactivating proteins (RIPs) were isolated from different parts of Luffa acutangula. Medicinal applications of RIP have received wide attention, as they possess various pharmacological activities including abortifacient (Jin, 1985), antifungal (Leah et al., 1991), anti-tumor (Bolognesi and Polito, 2004), antivirus and HIV-1 integrase inhibitory activities (Au et al., 2000; Wang et al., 2002).

Junkai et al. (2002) isolated two RIPs, luffaculin 1 (1) and 2 (2) from seeds by using sodium dodecyl sulfate-polyacrylamide gel electrophoresis (SDS-PAGE). The molecular mass of luffaculin 1 and 2 was found to be at $28 \mathrm{kD}$. Significant anticancer activity was shown by both RIP in human leukemia K562 cells with an $\mathrm{IC}_{50}$ value of $1.1 \times 10^{-6}$ and $2.0 \times 10^{\circ} \mathrm{mol} / \mathrm{L}$, respectively (Junkai et al., 2002).

Another RIP, luffangulin (3) was isolated from seed which inhibited cell-free translation $\left(\mathrm{IC}_{50}=3.5 \mathrm{nM}\right.$ ) but showed no activity against HIV-1 reverse transcriptase (Wang and Ng, 2002).

\section{Flavonoids}

Schilling and Heiser (1981) isolated total 10 flavonoids from different species of Luffa. Among these, only two flavonoids, i.e., apigenin-7-glucoside (4) and luteolin-7-glucoside (5) were present in leaf and flower (Figure 1) (Schilling and Heiser, 1981).

\section{Anthraquinone}

Anthraquinone derivative 1,8-dihydroxy-4-methylanthracene9,10-dione (6) was isolated using bioassay-guided approach from the ethanolic extract of aerial parts (Figure 2). Only five fractions 
TABLE 1 | Isolated phytochemicals of Luffa acutangula.

\begin{tabular}{|c|c|c|c|c|c|}
\hline $\begin{array}{l}\text { Compound } \\
\text { no. }\end{array}$ & Compound & Extract & Part & Type & Reference \\
\hline 1 & Luffaculin 1 & SDS-PAGE & Seed & Protein & Junkai et al., 2002 \\
\hline 3 & Luffangulin & - & Seed & Protein & Wang and $\mathrm{Ng}, 2002$ \\
\hline 4 & Apigenin-7-glucoside & - & Leaf and flower & Flavonoids & Schilling and Heiser, 1981 \\
\hline 5 & Luteolin-7-glucoside & - & Leaf and flower & Flavonoids & Schilling and Heiser, 1981 \\
\hline 7 & Myristic acid & Oil & Seed & Fatty acid & Kamel and Blackman, 1982 \\
\hline 8 & Palmitic acid & Oil & Seed & Fatty acid & Kamel and Blackman, 1982 \\
\hline 9 & Stearic acid & Oil & Seed & Fatty acid & Kamel and Blackman, 1982 \\
\hline 10 & Oleic acid & Oil & Seed & Fatty acid & Kamel and Blackman, 1982 \\
\hline 11 & Linoleic acid & Oil & Seed & Fatty acid & Kamel and Blackman, 1982 \\
\hline 13 & $\begin{array}{l}28-O-[O-\beta-D-x y l o p y r a n o s y l- \\
(1 \rightarrow 4)-O-\alpha-L- \\
\text { rhamnopyranosyl-( } 1 \rightarrow 2)-\alpha-L- \\
\text { arabinopyranosyl] ester } \\
\text { (Acutoside-B) }\end{array}$ & Methanolic extract & Aerial parts & Oleanane-type triterpene & Nagao et al., 1991 \\
\hline 14 & $\begin{array}{l}\text { 28-O-[O- } \beta \text {-D-xylopyranosyl- } \\
(1 \rightarrow 3)-O-\beta-D-x y l o p y r a n o s y l- \\
(1 \rightarrow 4)-O-\alpha-L- \\
\text { rhamnopyranosyl- }(1 \rightarrow 2)-\alpha-L- \\
\text { arabinopyranosyl] ester } \\
\text { (Acutoside-D) }\end{array}$ & Methanolic extract & Aerial parts & Oleanane-type triterpene & Nagao et al., 1991 \\
\hline 15 & 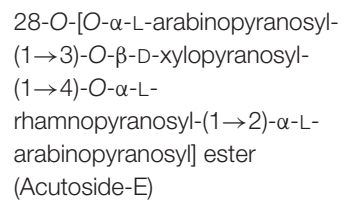 & Methanolic extract & Aerial parts & Oleanane-type triterpene & Nagao et al., 1991 \\
\hline 17 & $\begin{array}{l}28-O-\beta \text {-D-xylopyranosyl-( }(1 \rightarrow 3)- \\
{[O-\alpha-L-\text {-arabinopyranosyl- }} \\
(1 \rightarrow 3)-O-\beta \text {-D-xylopyranosyl- } \\
(1 \rightarrow 4)]-O-\alpha-L- \\
\text { rhamnopyranosyl- }(1 \rightarrow 2)-\alpha-L- \\
\text { arabinopyranosyl] ester } \\
\text { (Acutoside-G) }\end{array}$ & Methanolic extract & Aerial parts & Oleanane-type triterpene & Nagao et al., 1991 \\
\hline 18 & Machaelinic acid (Acutoside-C) & Methanolic extract & Aerial parts & Oleanane-type triterpene & Nagao et al., 1991 \\
\hline 19 & 3-Methyl-1-butanol & SPME coupled with GC-MS & Flower & Volatile components & Fernando and Grun, 2001 \\
\hline 20 & 4,5-Dimethyl-1-hexene & SPME coupled with GC-MS & Flower & Volatile components & Fernando and Grun, 2001 \\
\hline 21 & $\alpha$-Thujene & SPME coupled with GC-MS & Flower & Volatile components & Fernando and Grun, 2001 \\
\hline 22 & $\alpha$-Pinene & SPME coupled with GC-MS & Flower & Volatile components & Fernando and Grun, 2001 \\
\hline 23 & Sabinene & SPME coupled with GC-MS & Flower & Volatile components & Fernando and Grun, 2001 \\
\hline 24 & $\beta$-Pinene & SPME coupled with GC-MS & Flower & Volatile components & Fernando and Grun, 2001 \\
\hline 25 & $\beta$-Myrcene & SPME coupled with GC-MS & Flower & Volatile components & Fernando and Grun, 2001 \\
\hline 26 & D,L-Limonene & SPME coupled with GC-MS & Flower & Volatile components & Fernando and Grun, 2001 \\
\hline 27 & 1,8-Cineole & SPME coupled with GC-MS & Flower & Volatile components & Fernando and Grun, 2001 \\
\hline 28 & $\beta$-Ocimene (Z) & SPME coupled with GC-MS & Flower & Volatile components & Fernando and Grun, 2001 \\
\hline 29 & $\beta$-Ocimene $(E)$ & SPME coupled with GC-MS & Flower & Volatile components & Fernando and Grun, 2001 \\
\hline
\end{tabular}


TABLE 1 | Continued

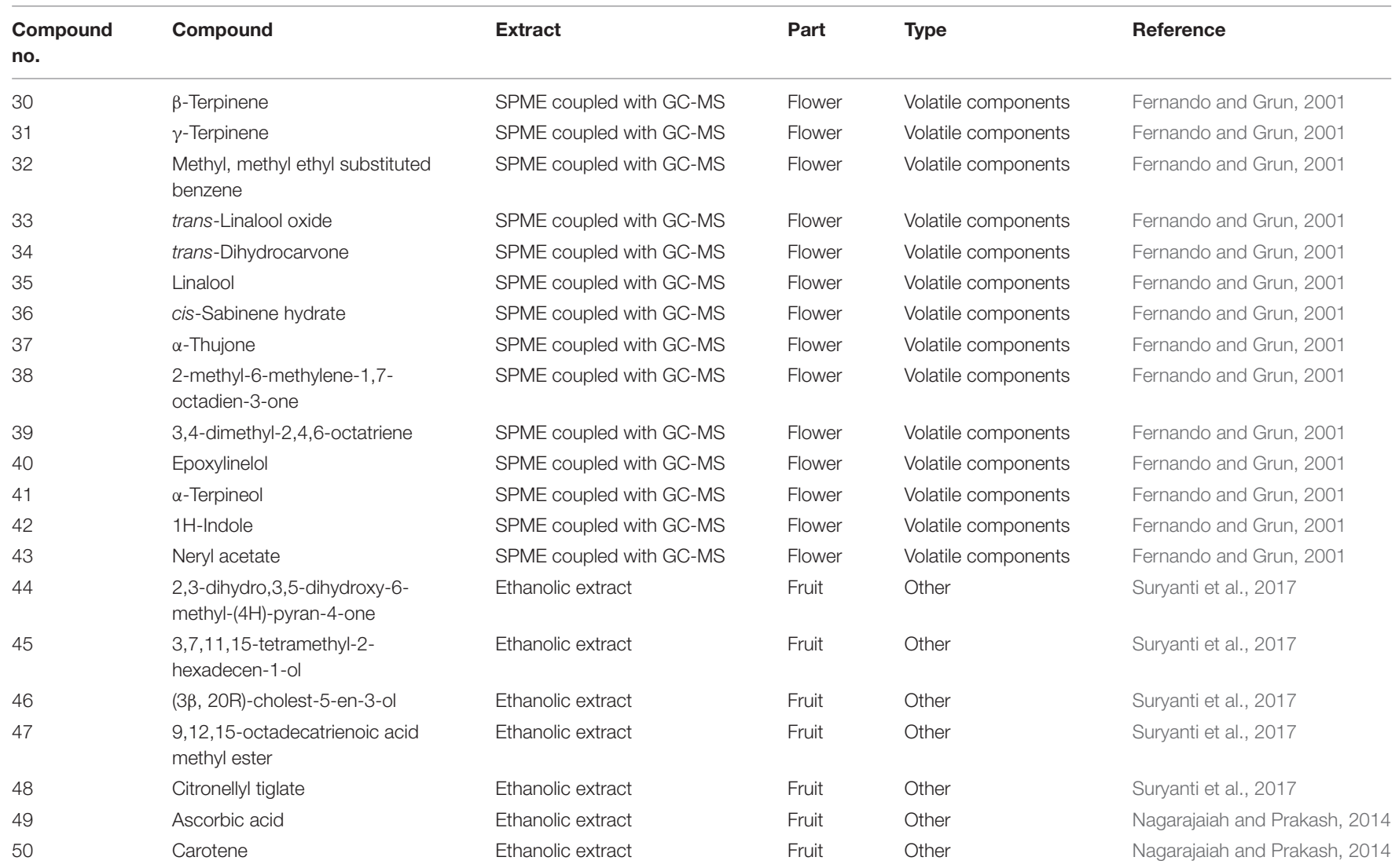<smiles>[R4]Oc1ccc(-c2oc3cc([R4])cc(O)c3c(=O)c2[R2])cc1[R16]</smiles>

(4) $\mathrm{R}_{1}=$ glucose, $\mathrm{R}_{2}=\mathrm{R}_{3}=\mathrm{R}_{4}=\mathrm{H}$

(5) $\mathrm{R}_{1}=$ glucose, $\mathrm{R}_{2}=\mathrm{R}_{4}=\mathrm{H}, \mathrm{R}_{3}=\mathrm{OH}$

FIGURE 1 | Flavonoids.

out of the fourteen were evaluated for anti-cancer activity against non-small cell lung cancer cells (NCI-H460). Fraction obtained at second position significantly decreased growth of cell with $\mathrm{IC}_{50}$ value of $10 \mathrm{mg} / \mathrm{ml}$ concentration (Vanajothi and Srinivasan, 2015).

\section{Fatty Acids}

Nutritional evaluation of seed showed the presence of fats, proteins, and minerals. The protein and fat obtained from the kernel were $39 \%$ and $44 \%$ of the total weight, respectively.

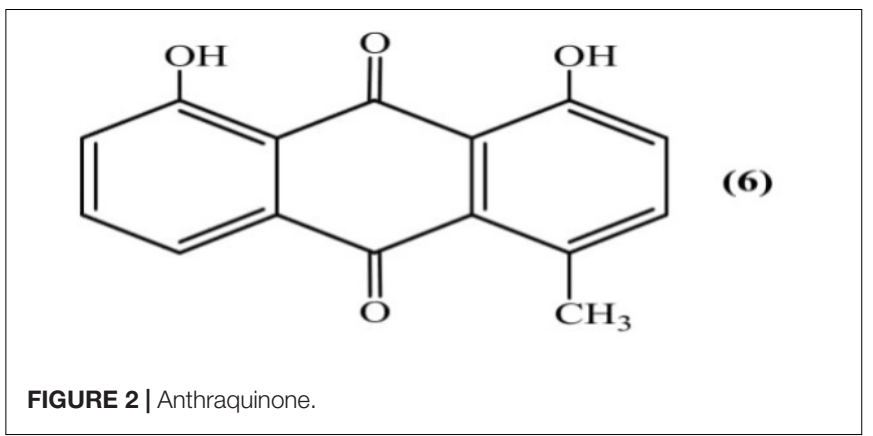

Investigational analysis of seed oil showed the presence of total saturated $(32.1 \%)$ and unsaturated $(67.9 \%)$ fatty acids which were recognized as myristic $(0.45 \%)(7)$, palmitic $(20.9 \%)(8)$, stearic $(10.8 \%)(\mathbf{9})$, oleic $(24.1 \%)(\mathbf{1 0})$, and linoleic $(43.7 \%)$ acid (11) (Figure 3). Iodine value, saponification value and acid value of the seed oil were found to be 99.5, 190.8, and 10.5 , respectively. The minerals like $\mathrm{Fe}, \mathrm{Ca}, \mathrm{Zn}, \mathrm{Cu}, \mathrm{P}$, and $\mathrm{Mg}$ were also identified from the seed kernel (Kamel and Blackman, 1982).

\section{Saponin Triterpene}

Seven saponins belonging to the oleanane - type triterpene were isolated from the aerial parts of Luffa acutangula (Figure 4). Methanolic extract was repeatedly chromatographed 


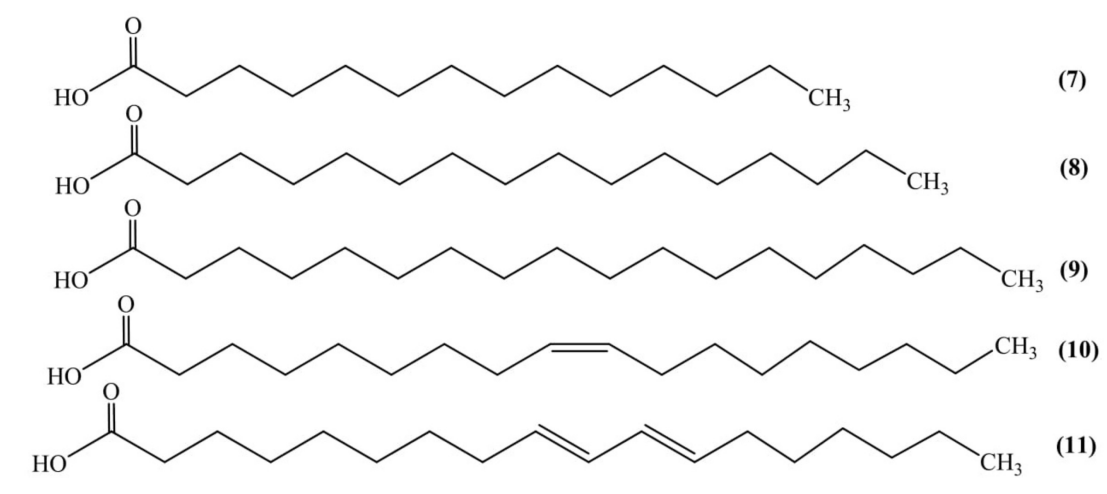

FIGURE 3 | Fatty acids.

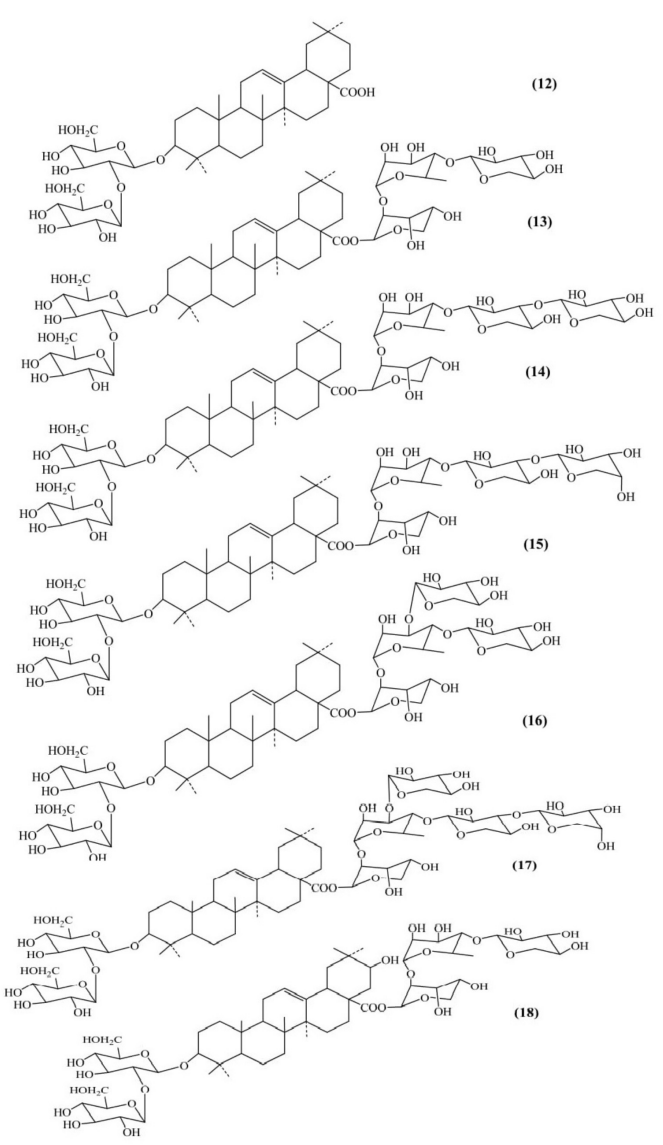

FIGURE 4 | Saponin triterpene.

on normal and reversed phase to obtain designated Acutosides A to G. The triterpene saponins isolated were named as: oleanolic acid 3-O- $\beta$-D-glucopyranosyl- $(1 \rightarrow 2)$ $\beta$-D-glucopyranoside (Acutoside-A) (12), 28-O-[O- $\beta$-Dxylopyranosyl- $(1 \rightarrow 4)$ - $O-\alpha$-L-rhamnopyranosyl- $(1 \rightarrow 2)-\alpha$-L-arabinopyranosyl] ester (Acutoside-B) (13), 28-O-[O- $\beta$-Dxylopyranosyl-( $(1 \rightarrow 3)$ - $O-\beta$-D-xylopyranosyl- $(1 \rightarrow 4)-O-\alpha$-L-rha- mnopyranosyl-( $1 \rightarrow 2)-\alpha$-L-arabinopyranosyl] ester (Acutoside-D) (14), 28-O-[O- $\alpha$-L-arabinopyranosyl- $(1 \rightarrow 3)-O-\beta$-Dxylopyranosyl- $(1 \rightarrow 4)-O-\alpha$-L-rhamnopyranosyl- $(1 \rightarrow 2)-\alpha$-L-arabinopyranosyl] ester (Acutoside-E) (15), 28-O-[O- $\beta$-Dxylopyranosyl- $(1 \rightarrow 3)$-[O- $\beta$-D-xylopyranosyl- $(1 \rightarrow 4)$-O- $\alpha$-L-rhamnopyranosyl- $(1 \rightarrow 2)-\alpha$-L-arabinopyranosyl] ester (Acutoside-F) (16), 28-O- $\beta$-D-xylopyranosyl- $(1 \rightarrow 3)-[O-\alpha-\mathrm{L}$-arabinopyranosyl-( $(1 \rightarrow 3)-O-\beta$-D-xylopyranosyl- $(1 \rightarrow 4)]-O-\alpha$-L-rhamnopyranosyl-( $(1 \rightarrow 2)-\alpha$-L-arabinopyranosyl] ester (Acutoside-G) (17). Acutoside- $\mathrm{C}$ (machaelinic acid, = 21- $\beta$-hydroxyoleanolic acid) (18) contains the same sugar moiety as that of Acutoside-B. The study revealed that Acutosides have a common prosapogenin structure but differ in the ester-linked sugar moieties structure (Nagao et al., 1991).

\section{Volatile Components}

Total 25 volatile components from flower were isolated using solid-phase microextraction (SPME) coupled with capillary gas chromatography/mass spectrometry (GC-MS) (Figure 5). Out of 25 compounds, 16 volatiles were positively identified and 9 were tentatively identified as 3-methyl-1-butanol (19); 4,5dimethyl-1-hexene (20); $\alpha$-thujene (21); $\alpha$-pinene (22); sabinene (23); $\beta$-pinene (24); $\beta$-myrcene (25); D,L-limonene (26); 1,8cineole (27); $\beta$-ocimene (Z) (28); $\beta$-ocimene (E) (29); $\beta$ terpinene (30); $\gamma$-terpinene (31); methyl, methyl ethyl substituted benzene (32); trans-linalool oxide (33); trans-dihydrocarvone (34); linalool (35); cis-sabinene hydrate (36); $\alpha$-thujone (37); 2-methyl-6-methylene-1,7-octadien-3-one (38); 3,4-dimethyl2,4,6-octatriene (39); epoxylinelol (40); $\alpha$-terpineol (41); $1 \mathrm{H}$ indole (42); neryl acetate (43) (Fernando and Grun, 2001).

\section{Other Phytoconstituents}

Six compounds were isolated and analyzed from ethanolic fruit extract using GC-MS named as: 2,3-dihydro,3,5-dihydroxy6-methyl-(4H)-pyran-4-one (44); 3,7,11,15-tetramethyl-2hexadecen-1-ol (45); $\quad(3 \beta, \quad 20 \mathrm{R})$-cholest-5-en-3-ol (46); $n$-hexadecanoic acid (08); 9,12,15-octadecatrienoic acid methyl ester (47) and citronellyl tiglate (48) (Figure 6) (Suryanti et al., 2017). 

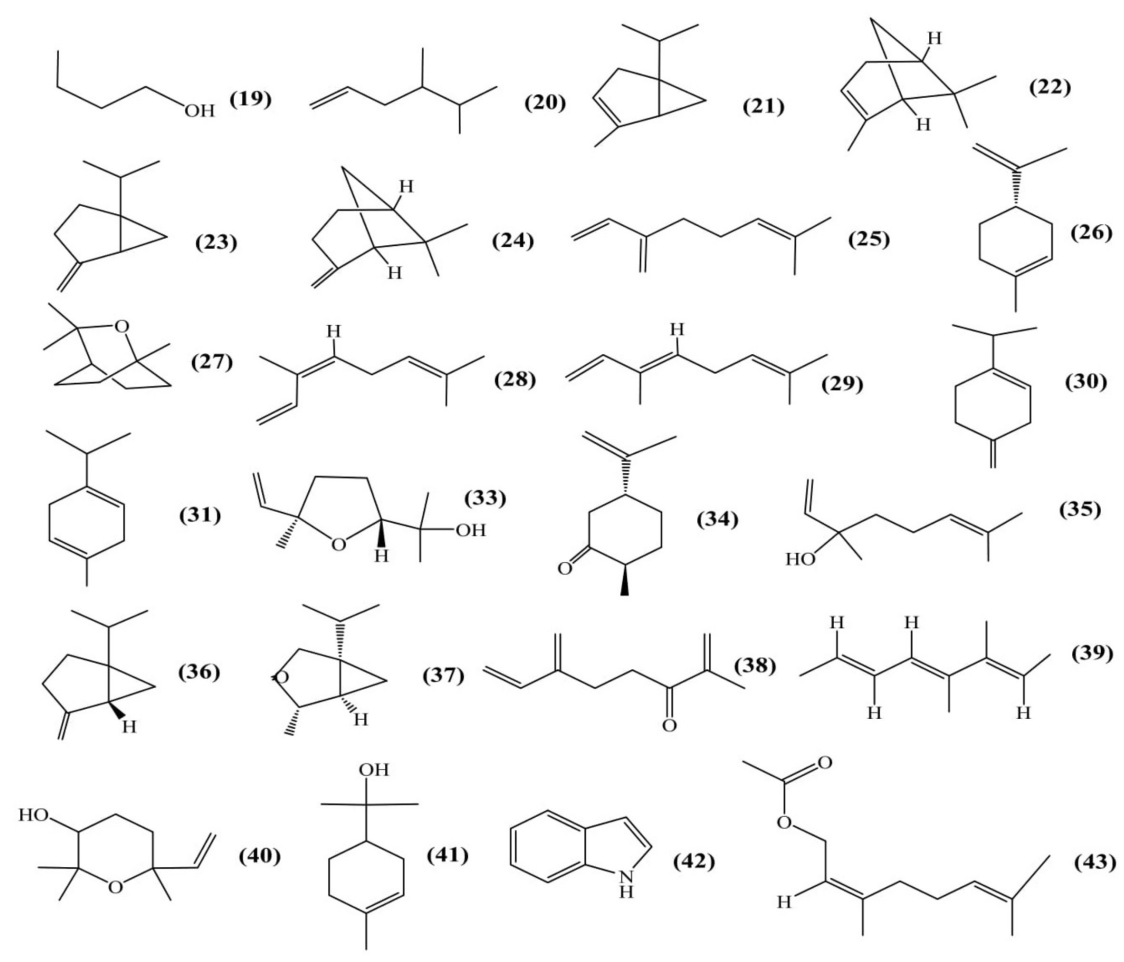

FIGURE 5 | Volatile components.

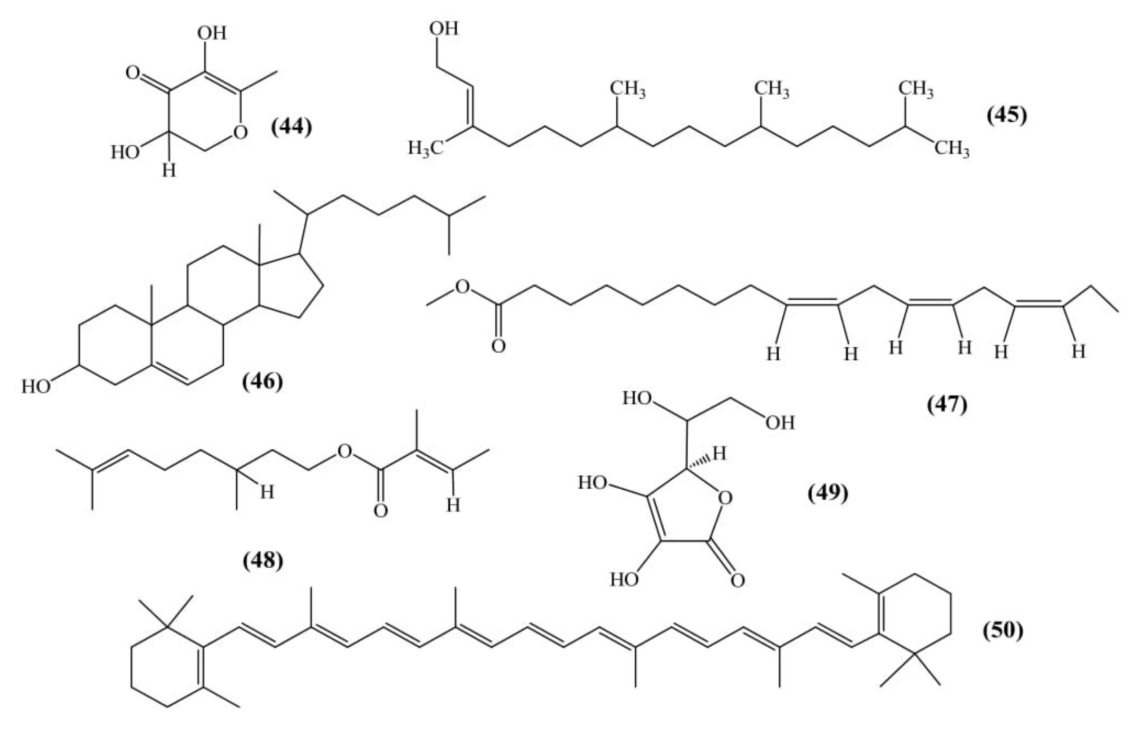

FIGURE 6 | Other phytoconstituents.

Nagarajaiah and Prakash (2014) evaluated physical characteristics and the chemical composition of the dehydrated fruit peel. The results exhibited the presence of iron $(4.74 \mathrm{mg})$, calcium (416 mg), phosphorous (233 mg), ascorbic acid (35 mg) (49), carotene (36.96 mg) (50) and tannin $(778.20 \mathrm{mg})$ per $100 \mathrm{gm}$ of peel (Figure 6) (Nagarajaiah and Prakash, 2014).

\section{PHARMACOLOGICAL ACTIVITY OF Luffa acutangula}

The extracts and purified compounds from Luffa acutangula have been investigated for various pharmacological activities using in vitro and in vivo models (Table 2 and Figure 7). Extracts from different parts of the plant exhibited potent 


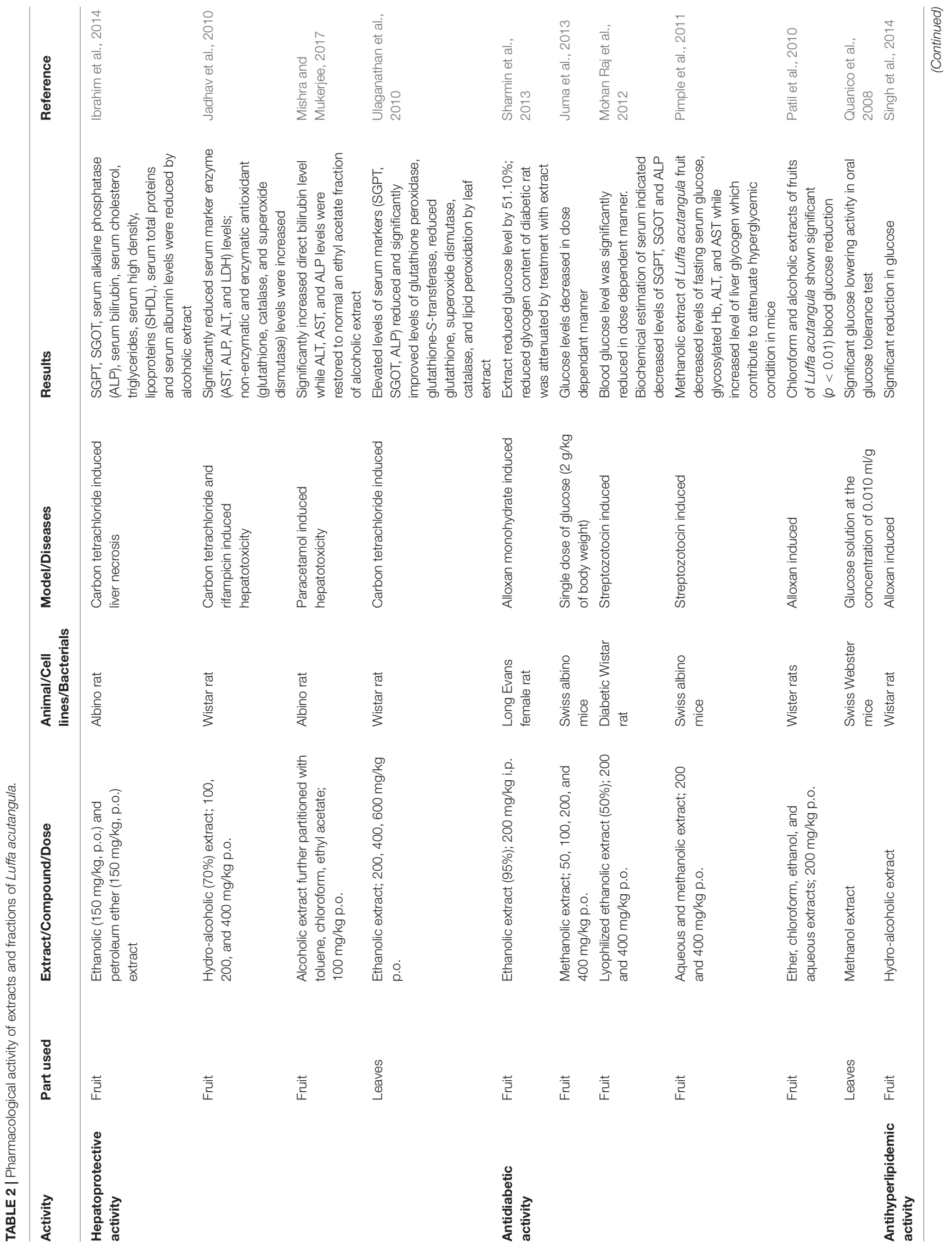




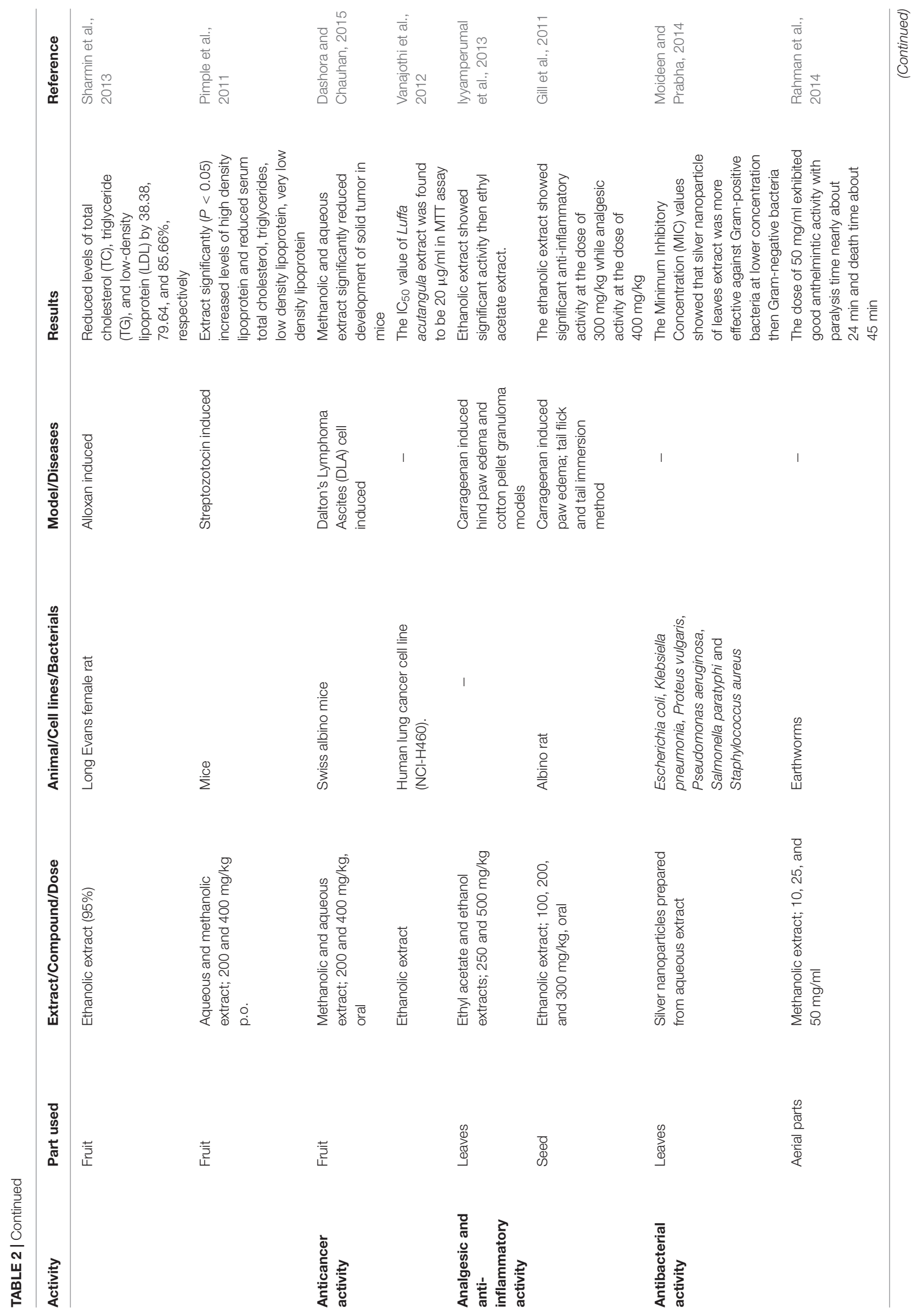




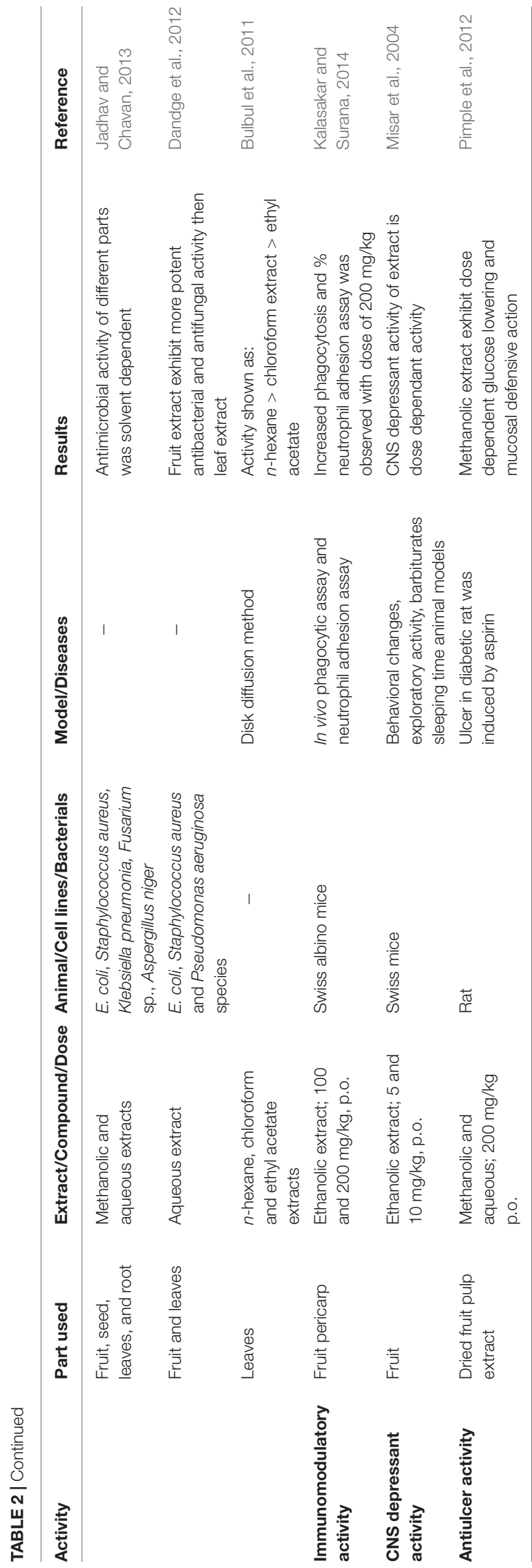

hepatoprotective, antidiabetic, antihyperlipidemic, antioxidant, anticancer, antibacterial, CNS depressant, immunomodulatory, and antiulcer activity. Some of these activities are discussed below.

\section{Hepatoprotective Activity}

Various studies have reported therapeutic potential of Luffa acutangula against liver diseases. Ethanolic fruit extract showed significant hepatoprotective activity compared to pet ether extract in carbon tetrachloride-induced liver necrosis. It also significantly reduced SGPT, SGOT, serum alkaline phosphatase (ALP), serum bilirubin, serum cholesterol, triglyceride (TG), serum high density lipoproteins (SHDLs), serum total proteins and serum albumin. Histopathological studies of liver showed early necrosis in petroleum ether extract while no necrosis was observed in the ethanolic extract, indicating the hepatoprotective potential of the latter (Ibrahim et al., 2014).

In another study, researchers investigated hepatoprotective activity of hydro-alcoholic (70\%) fruit extract against carbon tetrachloride and rifampicin-induced hepatotoxicity in Wistar rats. The doses of 100,200 , and $400 \mathrm{mg} / \mathrm{kg}$, p.o. significantly reduced serum marker enzyme (AST, ALP, ALT, and LDH) levels which attributed to the hepatoprotective action of the extract in the rat (Jadhav et al., 2010).

Hepatoprotective activity of different fractions of alcoholic fruit extract was evaluated by Mishra and Mukerjee (2017) against paracetamol induced liver toxicity. Toluene, chloroform, and ethyl acetate fractions of ethanolic extract were administered orally $(100 \mathrm{mg} / \mathrm{kg})$ and biochemical parameters were measured. Ethyl acetate fraction increased direct bilirubin level while ALT, AST, and ALP levels were restored to normal when compared with other fractions. Histopathological evaluation of live cells indicated the absence of necrosis with less vacuole formation (Mishra and Mukerjee, 2017).

Furthermore, Ulaganathan et al. (2010) screened hepatoprotective activity of ethanolic extract of the leaves against carbon tetrachloride. Carbon tetrachloride induced elevated levels of serum markers (SGPT, SGOT, and ALP) were brought to normal by oral administration of leaf extract. Tissue specific antioxidant activity of extract have been observed with the help of improved levels of glutathione peroxidase, glutathione-s-transferase, reduced glutathione, superoxide dismutase, catalase, and lipid peroxidation (Ulaganathan et al., 2010).

Taken together, these results support the traditional use of Luffa acutangula as hepatoprotective agent. However, hepatoprotective effect is still unconvincing as humans studies were not performed. Hence, ridge gourd is worth considering for treatment of hepatic diseases in human and therefore, should be extensively studied.

\section{Antidiabetic Activity}

Ancient literature reported the use of fruit juice in an adrenal variety of diabetes (Nadkarni, 1996). Various studies have been 


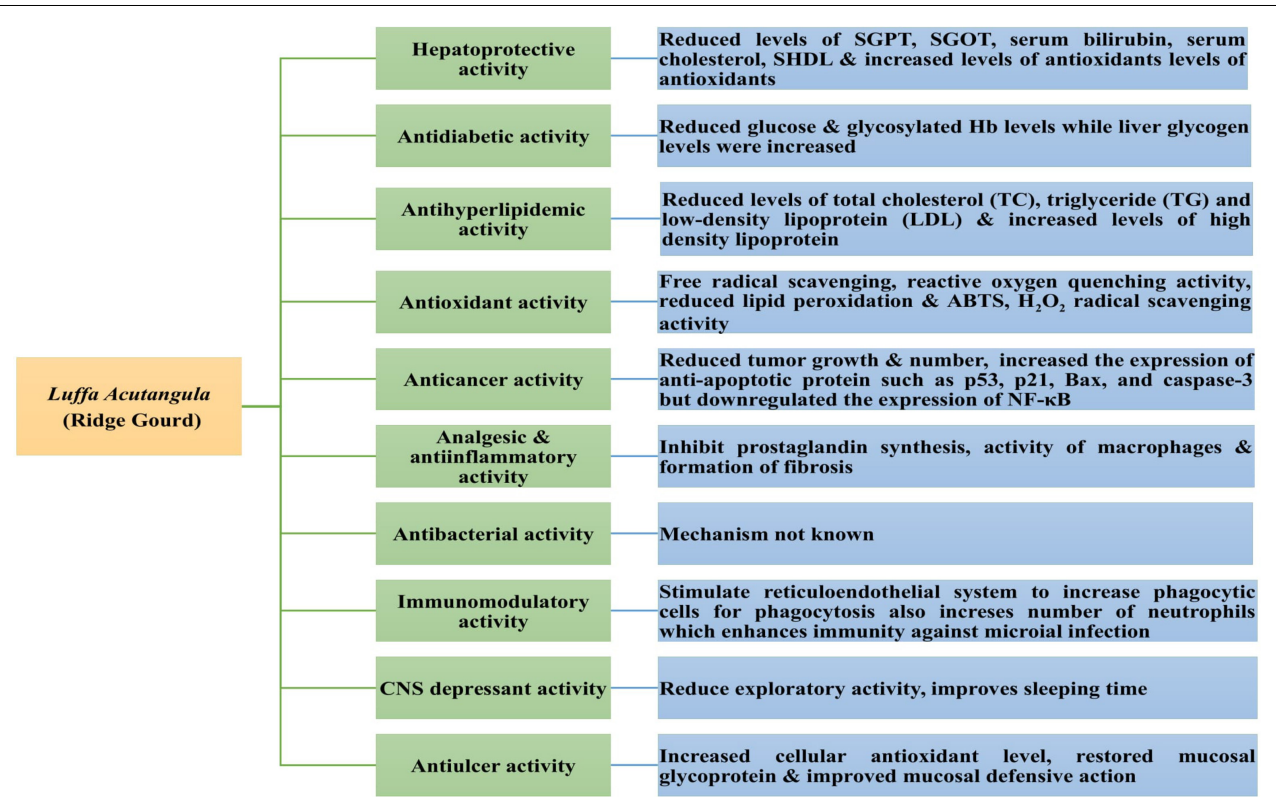

FIGURE 7 | Possible mechanisms for pharmacological activity.

performed to prove antidiabetic effect of the plant. Hypoglycemic activity of ethanolic extract (95\%) of Cucumis sativus, Lagenaria siceraria, and Luffa acutangula fruit was evaluated in Long Evans female rat against alloxan monohydrate. After $12 \mathrm{~h}$, all the extracts (200 mg/kg i.p.) reduced fasting blood glucose level by $67.38,65.39$, and $51.10 \%$, respectively. Reduced glycogen content $(75.32 \%)$ of the diabetic rat was attenuated by treatment with Luffa acutangula (149.35\%) ethanolic extract (Sharmin et al., 2013).

In another study, dose dependant glucose-lowering effect of methanolic fruit extract was observed in a Swiss albino mice (Juma et al., 2013).

Furthermore, Mohan Raj et al. (2012) examined the antidiabetic effect of the lyophilized ethanolic fruit extract (50\%) against streptozotocin-induced diabetic Wistar rats. Two different doses, i.e., 200 and $400 \mathrm{mg} / \mathrm{kg}$ were administered orally for 21 days and different biochemical parameters were evaluated. Blood glucose level was significantly reduced in a dose-dependent manner along with decreased serum levels of SGPT, SGOT, and ALP were observed. No significant changes were observed in body weight and food intake of the animal at the end of the study (Mohan Raj et al., 2012).

In another study, Pimple et al. (2011) investigated the hypoglycemic effect of an aqueous and methanolic fruit extract against streptozotocin-induced diabetes in Swiss albino mice.

After 21 days, decreased levels of fasting serum glucose, glycosylated $\mathrm{Hb}, \mathrm{ALT}$, and AST along with improved liver glycogen levels were observed which thought to be contributed to attenuate hyperglycemic condition in mice (Pimple et al., 2011).

Patil et al. (2010) compared the antidiabetic potential of leaves of Grewia asiatica, bark of Bombax ceiba, and fruits of Luffa acutangula against alloxan-induced diabetic Wistar rats. Ether, chloroform, ethanol, and aqueous extracts $(200 \mathrm{mg} / \mathrm{kg} \mathrm{b.w.)} \mathrm{of}$ each plant were administered orally and compared with standard glibenclamide (10 mg/kg b.w.). The results of the acute study showed significant blood glucose reduction from chloroform and alcoholic fruit extract (Patil et al., 2010).

Quanico et al. (2008) compared the hypoglycemic activity of methanol extract of Bixa orellana, Kyllinga monocephala, and Luffa acutangula leaves in an OGTT in Swiss Webster mice. Luffa acutangula extract showed significant glucose lowering activity when administered after $15 \mathrm{~min}$ of glucose load in the rat (Quanico et al., 2008).

In 2014, Singh et al. (2014) studied hydro-alcoholic extract of Luffa acutangula and Madhuca longifolia against alloxaninduced diabetic Wistar rat and observed a significant reduction in glucose level in the diabetic rat (Singh et al., 2014).

The results obtained under antidiabetic activity supports the traditional use of Luffa acutangula as an antidiabetic agent. Although it possess antidiabetic action, the effect in human is still unsatisfactory as in human diabetes treatment and should be studied extensively.

\section{Antihyperlipidemic Activity}

Sharmin et al. (2013) compared the lipid-lowering effect of ethanolic extract (95\%) of Cucumis sativus, Lagenaria siceraria, and Luffa acutangula fruit against alloxan monohydrate in Long Evans female rats. Extract significantly reduced total cholesterol (TC), TG, and low-density lipoprotein (LDL) levels by 38.38, 79.64 , and $85.66 \%$, respectively, in the serum of rat (Sharmin et al., 2013).

In another study, Pimple et al. (2011) established antihyperlipidemic activity of an aqueous and methanolic extract of fruit (200 and $400 \mathrm{mg} / \mathrm{kg}$ ) in streptozotocin-induced diabetic mice. Oral administration of extract for 21 days, 
significantly $(P<0.05)$ increased levels of high-density lipoprotein and reduced serum TC, TGs, low-density lipoprotein, very low-density lipoprotein (Pimple et al., 2011). Only few in vivo studies are available for antihyperlipidemic effect of Luffa acutangula. Moreover, further preclinical and clinical studies should be performed to check its profound effect on blood lipid levels.

\section{Anticancer Activity}

Anti-cancer potential of a methanolic and aqueous extract of fruit was studied in Dalton's Lymphoma Ascites (DLA) cell induced solid tumor model. In the study, Swiss albino mice received two doses (200 and $400 \mathrm{mg} / \mathrm{kg}$, oral) of each extract along with DLA cells. Development of solid tumor in mice was significantly diminished on treatment with both extracts (Dashora and Chauhan, 2015).

Furthermore, growth inhibitory effect of ethanolic extract of leaf was investigated on human lung cancer cell line (NCI-H460). The $\mathrm{IC}_{50}$ value was found to be at $20 \mu \mathrm{g} / \mathrm{ml}$ in MTT assay while cell lines showed high DCF fluorescence and significantly increased mitochondrial depolarization indicating anticancer activity of the extract (Vanajothi et al., 2012). However, not sufficient studies were undertaken to prove anticancer activity of the plant, due to which it is quite early to come to any conclusion. In vitro and in vivo anticancer studies are recommended to prove anticancer efficacy of plant.

\section{Analgesic and Anti-inflammatory Activity}

Anti-inflammatory effect of ethyl acetate and ethanol extracts of dried leaves was compared by Iyyamperumal et al. (2013) using carrageenan-induced hind paw edema and cotton pellet granuloma models. In acute carrageenan induced model, ethanolic extract showed $67.6 \%$ and $72.5 \%$ edema inhibition, while ethyl acetate showed $62.5 \%$ and $65 \%$ inhibition at the doses of 250 and $500 \mathrm{mg} / \mathrm{kg}$, respectively. Ethanolic extract showed $43.5 \%$ and $56.9 \%$ edema inhibition while ethyl acetate showed $36.5 \%$ and $52 \%$ inhibition at the doses of 250 and $500 \mathrm{mg} / \mathrm{kg}$, respectively, in chronic cotton pellet granuloma model (Iyyamperumal et al., 2013).

Gill et al. (2011) investigated analgesic and anti-inflammatory activity of ethanolic seed extract in the albino rats. Anti-inflammatory activity $(100,200$, and $300 \mathrm{mg} / \mathrm{kg}$, oral) was evaluated by carrageenan-induced paw edema and analgesic activity (200 and $400 \mathrm{mg} / \mathrm{kg}$, oral) by tail flick and tail immersion methods. Significant anti-inflammatory activity at the dose of $300 \mathrm{mg} / \mathrm{kg}$ while analgesic activity at the dose of $400 \mathrm{mg} / \mathrm{kg}$ was shown by seed extract (Gill et al., 2011). Taken together these reports support the traditional use of Luffa acutangula as pain relieving agent but the results are till unconvincing as humans are not involved in those studies. Hence, plant should be studied extensively as analgesic and anti-inflammatory agent.

\section{Antibacterial Activity}

Recently several studies have been performed to highlight the ability of various extracts of Luffa acutangula to prevent growth of microbial strains. Silver nano-particles prepared from an aqueous extract of leaves exert significant antimicrobial activity against Gram-positive bacteria than Gram-negative bacteria (Moideen and Prabha, 2014).

In vitro antimicrobial potential of methanolic and aqueous extracts of fruit, seed, leaves, and root was examined by Jadhav and Chavan (2013) using well diffusion assay. The maximum zone of inhibition was shown by methanolic extract with few exceptions. The methanolic extract of all parts showed potent inhibitory action against E. coli and Staphylococcus aureus while that of fruit and leaves showed significant inhibition against Klebsiella pneumonia. Also, inhibition of Fusarium sp. was more in methanolic extracts of fruit and root when compared with other parts. Both extracts of leaves were effective against Aspergillus niger. The overall result of the study indicated that antimicrobial activity of different parts was solvent dependent due to phyto-constituents present in it (Jadhav and Chavan, 2013).

In another study, potent antimicrobial and antifungal activity was exhibited by fruit extract when compared with leaf extract. The area of inhibition was higher in E. coli than in Staphylococcus aureus and Pseudomonas aeruginosa species (Dandge et al., 2012).

Chloroform and aqueous extracts of the fruit were screened for their antimicrobial and antifungal potential. Antimicrobial activity was evaluated against Gram-positive bacteria (Streptococcus aureus, Bacillus subtilis) and Gram-negative bacteria (Pseudomonas aeruginosa, Escherichia coli) while antifungal activity was evaluated against Candida albicans, Aspergillus niger, Aspergillus fumigates. The chloroform extract exhibited more potent activity against Gram-negative bacteria and antifungal activity in MIC study (Torvi and Hunashal, 2012).

Furthermore, antibacterial activity of $n$-hexane, chloroform and ethyl acetate extracts of leaves were investigated by Bulbul et al. (2011) using disk diffusion method. $n$-Hexane extract exhibited most potent inhibitory activity followed by chloroform extract whereas ethyl acetate extract showed little or no activity (Bulbul et al., 2011).

The above data suggested that plant possess good antibacterial activity which supports its traditional use, but further research is needed to isolate bioactive compounds and understand their antibacterial mechanism.

\section{Immunomodulatory Activity}

Ethanolic extract (100 and $200 \mathrm{mg} / \mathrm{kg}$, p.o.) of fruit pericarp were investigated for immunomodulatory activity in Swiss albino mice. The evaluation of phagocytic index revealed that administration of ethanolic extract $(200 \mathrm{mg} / \mathrm{kg})$ in Indian ink intoxicated mice led to increase in phagocytosis to $0.028 \pm 0.002$ $(P<0.01)$. Also the \% neutrophil adhesion in mice $(200 \mathrm{mg} / \mathrm{kg})$ was increased to $24.63 \pm 0.87 \%$ which was more than standard drug Levamisol (23.58 \pm 0.46\%) (Kalasakar and Surana, 2014). Further investigations are needed to provide evidence for its immunomodulatory activity.

\section{CNS Depressant Activity}

Misar et al. (2004) examined CNS depressant activity of ethanolic fruit extract (5 and $10 \mathrm{mg} / \mathrm{kg}$, p.o.) in Swiss mice. 
The dose of the extract was safe up to $50 \mathrm{mg} / \mathrm{kg}$ treatment without any morbidity. CNS depressant activity was evaluated using behavioral changes, exploratory activity and barbiturates sleeping time animal models. The result of the study showed that CNS depressant activity of extract is dose dependant (Misar et al., 2004). More in vitro and in vivo studies should be performed to confirm the CNS depressant action of plant.

\section{Antiulcer Activity}

Gastroprotective effect of dried fruit pulp extract (methanolic and aqueous) was investigated in NIDDM rat. Diabetes was induced by streptozotocin $(65 \mathrm{mg} / \mathrm{kg}$ i.p.) along with nicotinamide $(125 \mathrm{mg} / \mathrm{kg}$, i.p.) and ulcer in the diabetic rat was induced by aspirin $(200 \mathrm{mg} / \mathrm{kg}$, p.o.). Increased cellular SOD and catalase level while restored mucosal glycoprotein levels were observed in gastric mucosa of rat treated with methanolic extract. The aqueous extract was less effective than methanolic extract in altering delayed healing of gastric ulcer in diabetic rats. In addition, methanolic extract exhibited dose-dependent glucose lowering and mucosal defensive action (Pimple et al., 2012).

\section{TOXICITY STUDIES}

The $\mathrm{LD}_{50}$ value of an aqueous and methanolic fruit extract was obtained at $4 \mathrm{~g} / \mathrm{kg}$ body weight (Dashora and Chauhan, 2015). No mortality was observed for both extract during study period. The result indicated $\mathrm{LD}_{50}$ value for ethanolic extract at $500 \mathrm{mg} / \mathrm{kg}$, while that of petroleum ether extract at $350 \mathrm{mg} / \mathrm{kg}$ (Ibrahim et al., 2014). In another study, the cytotoxic activity of ethanolic and pet ether extracts of aerial parts was evaluated in brine shrimp (Artemia salina) lethality model. Different concentrations of both extracts ranging from 1 to $500 \mu \mathrm{g} / \mathrm{kg}$ were used for the study and the $\mathrm{LC}_{50}$ value of ethanolic and pet ether extract was found to be at $32.8 \pm 1.62$ and $175.65 \pm 10.80 \mu \mathrm{g} / \mathrm{kg}$, respectively. The cytotoxic activity of Luffa acutangula was attributed to the presence of tannin in the extract (Rahman et al., 2014). Furthermore, ethanolic and ethyl acetate extract of leaves were investigated for acute oral toxicity as per OECD guideline no. 423. Both extracts were found to be safe at dose of $2,000 \mathrm{mg} / \mathrm{kg}$ (Iyyamperumal et al., 2013).

Arunachalam et al. (2012) examined for the safety of an ethanolic extract of whole plant using acute and chronic toxicity studies. The acute toxicity study was performed according to OCED guideline no. 423 where defined doses $(2,000,1,000,500$, $50,5 \mathrm{mg} / \mathrm{kg}$ ) were administered to Wistar rats and parameters like change in body weight, changes in skin and fur, motor pattern and behavior pattern of animals were observed for 14 days. No toxicity and deaths were observed at the dose of $2,000 \mathrm{mg} / \mathrm{kg}$ level, therefore $1 / 20$ th $(100 \mathrm{mg} / \mathrm{kg}), 1 / 10$ th $(200 \mathrm{mg} / \mathrm{kg})$ and $1 / 5$ th $(400 \mathrm{mg} / \mathrm{kg}$ ) doses were selected for chronic toxicity study for 6 weeks. The hematological parameters ( $\mathrm{Hb}$ concentration, clotting time, neutrophils, eosinophils, lymphocytes, monocytes, RBC, and $\mathrm{WBC}$ ) evaluation of treated group showed no changes when compared to the control group. The biochemical parameters such as SGOT, SGPT, cholesterol, creatinine, urea, uric acid, protein, glucose and serum ALP also remained unchanged at the end of the study (Arunachalam et al., 2012).

Lyophilized ethanolic extract (50\%) of fruit was investigated for its safety by Mohan Raj et al. (2012) using OECD-423 guideline. The lyophilized formulation was found to be safe up to dose of 2,000 mg/kg without any mortality (Mohan Raj et al., 2012).

In a study performed by Pimple et al. (2012), methanolic and aqueous extracts were safe in Swiss albino mice up to the dose of $2,000 \mathrm{mg} / \mathrm{kg}$ p.o. No autonomic or behavioral changes were detected during first $24 \mathrm{~h}$. At the end of study no mortality was reported in animals even after 14 days of observation (Pimple et al., 2012).

The cytotoxicity of $n$-hexane, chloroform, and ethyl acetate extract of leaves were studied by Bulbul et al. (2011) using brine shrimp lethality bioassay with $n$-hexane extract of leaves showing significant $\mathrm{LC}_{50}$ value $(20.40 \mu \mathrm{g} / \mathrm{ml})$ when compared with chloroform $(21.25 \mu \mathrm{g} / \mathrm{ml})$ and ethyl acetate $(23.09 \mu \mathrm{g} / \mathrm{ml})$ (Bulbul et al., 2011).

Furthermore, abortifacient effect of fruit tea was evaluated by Fernandes et al. (2010) in pregnant Wistar female rats. On 15 th gestational day, pregnant female rats were treated with $L$ uffa acutangula fruit tea $(10 \mathrm{ml} / \mathrm{kg}$, p.o.) and the cesarean was done on the 21st day. No significant changes in body weight and no signs of maternal toxicity in the female rat were observed, but reduced fetus weight was reported. Since, weight is an important parameter in the fetus development, therefore, Luffa acutangula considered as fetoxic in nature (Fernandes et al., 2010).

In another study, acute toxicity of hydro-alcoholic (70\%) extract of fruit was investigated using OECD guideline no. 425 in mice. Animals were administered with different doses (500, $750,1,000$, and $2,000 \mathrm{mg} / \mathrm{kg}$ ) of hydro-alcoholic (70\%) extract and observed for $72 \mathrm{~h}$ for clinical signs, symptoms, and mortality. Result depicted that no mortality was observed up to $10 \mathrm{~g} / \mathrm{kg}$ dose level, even after $72 \mathrm{~h}$ (Jadhav et al., 2010).

Ulaganathan et al. (2010) evaluated ethanolic extract of leaves for acute toxicity study in Wistar rats. The extract was dissolved in Tween 80 solution and administered at the concentrations of $50,100,250,500,1,000$, and $>2,000 \mathrm{mg} / \mathrm{kg}$ by the oral route and the animals were observed for $72 \mathrm{~h}$ for any mortality or toxic symptoms. The result indicated that ethanolic extract of leaves did not show any toxic symptoms or mortality up to dose of $2,000 \mathrm{mg} / \mathrm{kg}$ (Ulaganathan et al., 2010).

Furthermore, ether, chloroform, ethanol, and aqueous fruit extracts were screened for safety using OECD guideline 423 and the study results exhibited $50 \%$ mortality with oral dose of 2,000 mg/kg (Patil et al., 2010).

\section{CONCLUSION AND FUTURE PERSPECTIVES}

The current review documented existing information on the ethnobotanical uses, phytochemistry, pharmacology, and toxicology of Luffa acutangula. The amount of data gathered 
from different studies revealed that the plant is rich in many nutrients and vast biological active constituents.

Various modern pharmacological studies have been conducted to appraise the traditional uses of Luffa acutangula and research data obtained supported the traditional claims. Plant possess the potential multiple biological and therapeutic activities in the management of hepatoprotective, antidiabetic, antiulcer, anticancer, CNS depressant, fungistatic, analgesic, antimicrobial, immunomodulatory, etc., which can be deciphered by the presence of various constituents like RIPs, flavonoids, fatty acid, triterpenoids, and volatile components in it.

However, extensive investigations are required to formulate co-relations between the biological activities and chemical nature of the bioactive compounds deracinated from herb. Toxicity evaluation of plants is very important to understand their safety profile. To this end, no human studies have been performed to evaluate toxic effects of Luffa acutangula. The acute toxicity studies of the plant in preclinical models revealed fetotoxic nature as it reduces the weight of the fetus during pregnancy. However, further clinical evaluation must be performed to perceive the detailed effect of plant on human fetus. No other toxic effects were observed in preclinical studies indicating the safe use of plant.

\section{REFERENCES}

Arunachalam, A., Selvakumar, S., and Jeganath, S. (2012). Toxicological studies on ethanol extract of Luffa acutangula in albino wistar rats. Int. J. Curr. Pram. Clin. Res. 2, 29-33.

Au, K., Collins, A., Lam, L., Ng, T., Fong, P., and Wan, C. (2000). The plant ribosome inactivating proteins luffin and saporin are potent inhibitors of HIV-1 integrase. FEBS Lett. 471, 169-172. doi: 10.1016/S0014-5793(00) 01389-2

Basu, B., and Kirtikar, K. (1987). Indian Medicinal Plants, Vol. 2, 2nd Edn, Dehradun: International Book Distributors.

Bolognesi, A., and Polito, L. (2004). Immunotoxins and other conjugates: preclinical studies. Mini Rev. Med. Chem. 4, 563-583. doi: 10.2174/ 1389557043403864

Bulbul, J., Zulfiker, A., Hamid, K., Khatun, M., and Begum, Y. (2011). Comparative study of in vitro antioxidant, antibacterial and cytotoxic activity of two bangladeshi medicinal plants-Luffa cylindrica L. and Luffa acutangula. Pharmacogn. J. 3, 59-66. doi: 10.5530/pj.2011.23.9

Dandge, S., Rothe P., and Pethe A. (2010). Antimicrobial activity and pharmacognostic study of Luffa acutangula Roxb var amara on some deuteromycetes fungi. Int. J. Sci. Inn. Discover. 2, 191-196.

Dandge, S., Rothe, P., and Pethe, A. (2012). Antimicrobial activity and pharmacognostic study of Luffa acutangula (1) Roxb var amara on some deuteromycetes fungi. Int. J. Sci. Inn. Discover. 2, 191-195.

Danish, M., Singh, P., Mishra, G., Srivastava, S., Jha, K., and Khosa, R. (2011). Cassia fistula linn.(Amulthus)-an important medicinal plant: a review of its traditional uses, phytochemistry and pharmacological properties. J. Nat. Prod. Plant Res. 1, 101-118.

Das, S., and Basu, P. (1997). Effect of cephalexin on flowering fruit setting and development of Luffa acutangula Roxb. Indian J. Plant Physiol. 2, 18-20.

Dashora, N., and Chauhan, L. (2015). In vitro antioxidant and in vivo anti-tumor activity of Luffa acutangula against Dalton's Lymphoma Ascites (DLA) cells bearing mice. J. Chem. Pharm. Res. 7, 940-945.

Encyclopaedia Britannica (2018). Encyclopaedia Britannica. Available at: http:// www.britannica.com/plant/Cucurbitaceae [accessed April 1, 2018].

Fernandes, L., Cordeiro, L., and Soto-Blanco, B. (2010). Luffa acutangula Roxb. tea promotes developmental toxicity to rats. J. Anim. Vet. Adv. 9, 1255-1258. doi: $10.3923 /$ javaa.2010.1255.1258
From present compilation, it is observed that researchers need to establish the relationship between structure and function along with clinical studies on the efficacy of plants chemical components. Furthermore, validating the link between the traditional uses and therapeutic effects should be carried out further, and the toxicity of this plant also should be studied systematically. Well designed and strictly controlled clinical trials are also needed to validate safety and efficacy of dose before its recommendations for human consumption.

\section{AUTHOR CONTRIBUTIONS}

SB and PS conceived the review. PS drafted the manuscript. SB was involved in the editing process. Both the authors read and approved the final version of the manuscript.

\section{ACKNOWLEDGMENTS}

We acknowledge School of Pharmacy and Technology Management, SVKM's NMIMS, Shirpur Campus, Maharashtra, India for providing support and assistance for this review article.

Fernando, L., and Grun, I. (2001). Headspace-SPME analysis of volatiles of the ridge gourd (Luffa acutangula) and bitter gourd (Momordica charantia) flowers. Flavour Fragr. J. 16, 289-293. doi: 10.1002/ff. 999

Gill, S., Arora, R., and Kumar, R. (2011). Evaluation of antioxidant, antiinflammatory and analgesic potential of the Luffa acutangula Roxb. Var. amra. Phytochemistry 5, 201-208. doi: 10.3923/rjphyto.2011.201.208

Ibrahim, M., Abid, M., Abid, Z., Ahamed, M. F., and Aara, A. (2014). Phytochemical and hepatoprotective activity of fruit extracts of Luffa acutangula Roxb.Var.amara. J. Med. Pharm. Inn. 1, 49-56.

Iyyamperumal, U., Periyannanc, M., and Ilavarasand, R. (2013). Antiinflammatory and in vitro antioxidant potential of extracts leaves of Luffa acutangula (var) amara in rodent model (rats). Int. J. Pharm. Pharm. Sci. 5(Suppl. 2), 79-83.

Jadhav, B., Thakare, N., Suralkar, A., Deshpande, D., and Naik, R. (2010). Hepatoprotective activity of Luffa acutangula against CCl4 and rifampicin induced liver toxicity in rats: a biochemical and histopathological evaluation. Indian J. Exp. Biol. 48, 822-829.

Jadhav, S., and Chavan, N. (2013). Evaluation of antimicrobial activity of Luffa acutangula (L.) Roxb. var. amara (Roxb.) Clarke. Int. J. Adv. Res. 1, 323-326.

Jin, C. (1985). Intra-amniotic injection of crystal trichosanthin for induction of labour in second trimester pregnancy. Shengzhi Yu Biyun 5, 15-17.

Juma, A., Pervin, R., Azad, M., Islam, M., Rahman, S., Kabir, M., et al. (2013). Antihyperglycemic and antinociceptive activity of methanolic extract of Luffa acutangula fruits. Adv. Nat. Appl. Sci. 7, 435-441.

Junkai, L., Chen Minghuang, C., Jieming, X., Rong, Z., Xiaoming, Y., Xiaoli, S., et al. (2002). Purification and characterization of two luffaculins, ribosomeinactivating proteins from seeds of Luffa acutangula. Chin. J. Biochem. Mol. Biol. $18,609-613$.

Kalasakar, M., and Surana, S. (2014). Free radical scavenging, immunomodulatory activity and chemical composition of Luffa acutangula Var. amara (Cucurbitaceae) pericarp. J. Chilean Chem. Soc. 59, 2299-2302. doi: 10.4067/S0717-97072014000100012

Kamel, B. S., and Blackman, B. (1982). Nutritional and oil characteristics of the seeds of angled Luffa Luffa acutangula. Food Chem. 9, 277-282. doi: 10.1016/ 0308-8146(82)90078-4

Kanaka, R., Narasinga, R., Venkateshwarlu, M., Sammaiah, D., Anitha, U., and Ugandhar, T. (2013). Studies on the medicinal plant biodiversity in forest 
ecosystem of Mahadevpur forest of Karimnagar (A.P.) India. Biosci. Discov. 4, 82-88.

Katewa, S., Chaudhary, B., and Jain, A. (2004). Folk herbal medicines from tribal area of Rajasthan, India. J. Ethnopharmacol. 92, 41-46. doi: 10.1016/j.jep.2004. 01.011

Leah, R., Tommerup, H., Svendsen, I., and Mundy, J. (1991). Biochemical and molecular characterization of three barley seed proteins with antifungal properties. J. Biol. Chem. 266, 1564-1573.

Lucas, E., Dumancas, G., Smith, B., and Arjmandi, B. (2010). Health benefits of bitter melon (Momordica charantia). Bioact. Foods Promot. Health 35, 525-549. doi: 10.1016/B978-0-12-374628-3.00035-9

Mahbubar, R. (2013). Ethno-medico-botanical studies on cucurbits of Rajshahi division, Bangladesh. J. Med. Plants Stud. 1, 118-125.

Misar, A., Upadhye, A., and Mujumdar, A. (2004). CNS depressant activity of ethanol extract of Luffa acutangula fruits in mice. Indian J. Pharm. Sci. 66, 463-465.

Mishra, B., and Mukerjee, A. (2017). In vivo and ex vivo evaluation of Luffa acutangula fruit extract and its fractions for hepatoprotective activity in wistar rats. Int. J. Pharm. Sci. Res. 8, 5227-5233.

Mohan Raj, S., Mohammed, S., Vinoth Kumar, S., Santhosh Kumar, C., and Debnath, S. (2012). Antidiabetic effect of Luffa acutangula fruits and histology of organs in streptozotocin induced diabetic in rats. Res. J. Pharmacogn. Phytochem. 4, 64-69.

Moideen, R., and Prabha, A. (2014). Green synthesis of silver nano particles using Luffa acutangula roxb. var. amara. lin and its antibacterial activity. Int. J. Pharm. Bio Sci. 5, 1051-1061.

Munshi, A., Behera, T., Sureja, A., and Kumar, R. (2010). Occurrence and preliminary characterization of gynoecious ridge gourd ( $\mathrm{Luffa}$ acutangula (L.) Roxb) in a natural population. Cucurbit Genet. Coop. Rep. 33-34, 57-59.

Nadkarni, A. (1996). Dr. K. M. Nadkarni's Indian materia medica: with ayurvedic, unani-tibbi, siddha, allopathic, homeopathic, naturopathic \& home remedies, appendices \& indexes. 1. Pop. Prakashan 1, 751-752.

Nagao, T., Tanaka, R., Iwase, Y., Hanazono, H., and Okabe, H. (1991). Studies on the constituents of Luffa acutangula Roxb. I. Structures of acutosides A-G, oleanane-type triterpene saponins isolated from the herb. Chem. Pharm. Bull. 39, 599-606. doi: 10.1248/cpb.39.599

Nagarajaiah, B., and Prakash, J. (2014). Chemical composition and bioactive potential of dehydrated peels of Benincasa hispida, Luffa acutangula, and Sechium edule. J. Herbs Spices Med. Plants 21, 193-202. doi: 10.1080/10496475. 2014.940437

Patil, P., Patel, M., and Bhavsar, C. (2010). Comparative antidiabetic activity of some herbal plants extracts. Int. J. Pharm. Sci. 1, 12-19.

Pimple, B., Kadam, P., and Patil, M. (2011). Antidiabetic and antihyperlipidemic activity of Luffa acutangula fruit extracts in streptozotocin induced NIDDM rats. Asian J. Pharm. Clin. Res. 4, 156-163.

Pimple, B., Kadam, P., and Patil, M. (2012). Protective effect of Luffa acutangula extracts on gastric ulceration in NIDDM rats: role of gastric mucosal glycolproteins and antioxidants. Asian Pac. J. Trop. Med. 5, 610-615. doi: 10.1016/ S1995-7645(12)60126-6

Quanico, J., Amor, E., and Perez, G. (2008). Analgesic and hypoglycemic activities of Bixa orellana, Kyllinga monocephala and Luffa acutangula. Philipp. J. Sci. 137, 69-76.
Quattrocchi, U. (2012). CRC World Dictionary of Medicinal and Poisonous Plants Common Names, Scientific Names, Eponyms, Synonyms and Etymology. Boca Raton, FL: CRC Press. doi: 10.1201/b16504

Rahman, M., Ahmed, A., Sunny, S., Atanu, S., Faruque, A., Rana, S. (2014). Invitro evaluation of cytotoxic and anthelmintic activity of Luffa acutangula, Luffa aegyptiaca and Momordica cochinchinensis. Br. J. Pharm. Res. 4, 267-277. doi: 10.9734/BJPR/2014/4613

Samvatsar, S., and Diwanji, V. (2000). Plant sources for the treatment of jaundice in the tribal's of western Madhya Pradesh of India. J. Ethnopharmacol. 73, 313-316. doi: 10.1016/S0378-8741(00)00274-9

Schilling, E., and Heiser, C. (1981). Flavonoids \& the systematics of Luffa. Biochem. Syst. Ecol. 9, 263-265. doi: 10.1016/0305-1978(81)90006-5

Sharmin, R., Khan, M., Akhter, M., Alim, A., Islam, M., Anisuzzaman, A., et al. (2013). Hypoglycemic and hypolipidemic effects of cucumber, white pumpkin and ridge gourd in alloxan induced diabetic rats. J. Sci. Res. 5, 161-170.

Singh, H., Arora, S., Mani, M., Mahaur, K., and Chandra, P. (2014). Development of multicomponent formulation of herbal drugs for evaluation of antidiabetic activity. Pharm. Lett. 6, 219-223.

Suryanti, V., Marliyana, S., and Astuti, I. (2017). Chemical constituents of Luffa acutangula (L.) Roxb fruit. IOP conf. Ser. Mater. Sci. Eng. 193:012050.

Torvi, J., and Hunashal, R. (2012). A study on antimicrobial activity of extracts of Luffa acutangula var amara fruits. Int. J. Pharma Bio Sci. 3, 678-685.

Ulaganathan, I., Divya, D., Radha, K., Vijayakumar, T., and Dhanaraju, M. (2010). Protective effect of Luffa acutangula (var) amara against carbon tetrachlorideinduced hepatotoxicity in experimental rats. Res. J. Biol. Sci. 5, 615-624. doi: 10.3923/rjbsci.2010.615.624

Vanajothi, R., and Srinivasan, P. (2015). Bioassay-guided isolation and identification of bioactive compound from aerial parts of Luffa acutangula against lung cancer cell line NCI-H460. J. Recept. Signal Transduct. Res. 35, 295-302. doi: 10.3109/10799893.2014.977451

Vanajothi, R., Sudhaa, A., Manikandanb, R., Rameshthangamc, P., and Srinivasana, P. (2012). Luffa acutangula and Lippia nodiflora leaf extract induces growth inhibitory effect through induction of apoptosis on human lung cancer cell line. Biomed. Prev. Nutr. 2, 287-293. doi: 10.1016/j.bionut.2012.03.002

Wang, H., and Ng, T. B. (2002). Luffangulin, a novel ribosome inactivating peptide from ridge gourd (Luffa acutangula) seeds. Life Sci. 70, 899-906. doi: 10.1016/ S0024-3205(01)01466-7

Wang, H., Nie, L., Tam, C., Huang, H., and Zheng, T. (2002). Anti-HIV-1 property of trichosanthin correlates with its ribosome inactivating activity. FEBS Lett. 531, 295-298. doi: 10.1016/S0014-5793(02)03539-1

Conflict of Interest Statement: The authors declare that the research was conducted in the absence of any commercial or financial relationships that could be construed as a potential conflict of interest.

Copyright (c) 2018 Shendge and Belemkar. This is an open-access article distributed under the terms of the Creative Commons Attribution License (CC BY). The use, distribution or reproduction in other forums is permitted, provided the original author(s) and the copyright owner(s) are credited and that the original publication in this journal is cited, in accordance with accepted academic practice. No use, distribution or reproduction is permitted which does not comply with these terms. 